\title{
A quantitative method for detecting deposits of amyloid A protein in aspirated fat tissue of patients with arthritis
}

\author{
Bouke P C Hazenberg, Pieter C Limburg, Johan Bijzet, Martin H van Rijswijk
}

\begin{abstract}
Objective-To describe a new, quantitative, and reproducible method for detecting deposits of amyloid $A$ protein in aspirated fat tissue and to compare it with smears stained with Congo red.

Methods-After extraction of at least 30 mg of abdominal fat tissue in guanidine, the amyloid A protein concentration was measured by a monoclonal antibodybased sandwich ELISA.

Results-The concentrations in 24 patients with arthritis and AA amyloidosis (median 236, range 1.1-8530 $\mathrm{ng} / \mathrm{mg}$ tissue) were higher $(p<0.001)$ than in nonarthritic controls, uncomplicated rheumatoid arthritis, and other types of systemic amyloidosis (median 1.1 , range 1.1-11.6 ng/mg tissue). Patients with extensive deposits, according to Congo red staining, had higher concentrations than patients with minute deposits.

Conclusion-This is a new, quantitative, and reproducible method for detecting deposits of amyloid A protein in aspirated fat tissue of patients with arthritis, even when minute deposits are present as detected in smears stained with Congo red. (Ann Rheum Dis 1999;58:96-102)
\end{abstract}

About $3 \%$ to $10 \%$ of the patients with rheumatoid arthritis develop AA amyloidosis in the course of their disease. ${ }^{12}$ Deposits of amyloid A protein are found in many tissues and in the walls of blood vessels throughout the whole body. These amyloid A protein deposits are derived from serum amyloid A protein (SAA), an acute phase reactant, which is produced by the liver during inflammation. If accumulation of amyloid A protein deposition cannot be stopped or delayed, serious renal and gastrointestinal problems will arise, and most patients will die within two to four years. ${ }^{34}$ However, if the underlying inflammation is adequately suppressed, further loss of renal function and increase of proteinuria can be stopped and survival will improve..$^{5-7}$ Therefore, AA amyloidosis should be diagnosed as early as possible.

Amyloid is diagnosed by the typical green birefringence in polarised light of a tissue biopsy specimen stained with the Congo red dye. Subsequent immunohistochemistry with anti-AA antibodies establishes the amyloid A nature of the amyloid involved. ${ }^{8}$ However, minute deposits of amyloid are hard to detect in Congo red stained biopsy specimens, and can be overlooked easily. ${ }^{9}$ A quantitative biochemical measurement of the amyloid A protein concentration in tissue might therefore improve the diagnostic yield of a biopsy in an independent way. An additional advantage will be the characterisation of the amyloid as the amyloid A protein type. Amyloid A protein has already been quantified in small samples (10-60 mg) of mouse and human necropsy tissues of the spleen. ${ }^{10}$ However, the clinician who treats patients with arthritis needs a procedure that is easy to perform routinely during life, which can be repeated at intervals, and with results that are reproducible and can be obtained within days. In patients, abdominal subcutaneous fat tissue is very appropriate for this purpose: this tissue is easy to obtain by aspiration, and smears are frequently found to be positive for amyloid by staining these with Congo red. ${ }^{11}$

The aim of this study was to develop a new, clinically usable, quantitative, and reproducible method for detecting deposits of amyloid A protein in aspirated fat tissue of patients with arthritis. The new method was tested in patients with arthritis and AA amyloidosis, in non-arthritic controls, in patients with rheumatoid arthritis without AA amyloidosis, and in patients with other types of systemic amyloidosis. In all patients and controls, the new method was compared with the standard method for detecting amyloid deposits in smears of fat tissue stained with Congo red.

\section{Methods}

STUDY DESIGN

We describe a monoclonal antibody-based sandwich enzyme linked immunosorbent assay (ELISA) for measuring the amyloid A protein concentration in extracts of human abdominal fat tissue. This ELISA for quantifying the amyloid A protein concentration was tested in various groups of patients and the results were compared with the semi-quantitative scores of fat tissue smears stained with Congo red. The influence of the concentration of serum amyloid A protein in simultaneously obtained blood samples was investigated as well as the effect of the duration of the AA amyloidosis, the duration of the arthritis, and the age of the patients. Immunoblotting of the fat extracts was used to determine the size of the amyloid $\mathrm{A}$ protein fragments involved.

Rheumatology, University Hospital, PO Box 30.001, 9700 RB Groningen, the Netherlands.

\section{PATIENTS}

The new method was tested from January 1997 until February 1998 in 24 patients with arthritis and biopsy confirmed AA amyloidosis (AA 
Table 1 Patients'characteristics, serum acute phase proteins, and fat tissue measurements

\begin{tabular}{|c|c|c|c|c|}
\hline & Control & $R A$ & $A A$ & $A L / A T T R$ \\
\hline \multicolumn{5}{|l|}{ Patients } \\
\hline Number of patients & 22 & 25 & 24 & 25 \\
\hline Men/women & $11 / 11$ & $9 / 16$ & $5 / 19$ & $10 / 15$ \\
\hline Age $(y)$ & $43.5(24-70) \dagger$ & $69(42-82)$ & $63(29-85)$ & $59(34-84)$ \\
\hline Duration of arthritis (y) & NA & $20(2-57)$ & $22.5(9-41)$ & NA \\
\hline Duration of amyloidosis (months) & NA & NA & $9(0-139)$ & $13(0-162)$ \\
\hline \multicolumn{5}{|l|}{ Serum acute phase proteins } \\
\hline SAA concentration $(\mathrm{mg} / \mathrm{l})$ & $0.4(0.4-146) \dagger$ & $9.3(3.1-295)$ & $14(0.4-229)$ & $0.4(0.4-87) \ddagger$ \\
\hline CRP concentration $(\mathrm{mg} / \mathrm{l})$ & $2(1-198)^{\star}$ & $15(2-210)$ & $17.5(1-84)$ & $3(1-58) \dagger$ \\
\hline \multicolumn{5}{|l|}{ Fat tissue } \\
\hline Amyloid A (ng/mg fat tissue) & $1.1(1.1-4.2) \ddagger$ & $1.1(1.1-5.4) \ddagger$ & $236(1.1-8530)$ & $1.1(1.1-11.6) \ddagger$ \\
\hline Amyloid A ( $\mu \mathrm{g} / \mathrm{mg}$ protein) & $0.11(0.11-0.88) \ddagger$ & $0.11(0.11-0.56) \ddagger$ & $31.5(0.11-515)$ & $0.11(0.11-1.24) \ddagger$ \\
\hline Protein ( $\mu \mathrm{g} / \mathrm{mg}$ fat tissue) & $6.6(3.8-16.1)$ & $7.2(2.7-21.6)$ & $9.5(3.5-27.3)$ & $10.1(4.3-39.3)$ \\
\hline Total wet weight $(\mathrm{mg})$ & $87(31-278)$ & $88(32-361)$ & $107(30-415)$ & $79(38-244)$ \\
\hline
\end{tabular}

Data are median and (range). $\mathrm{RA}=$ rheumatoid arthritis without $\mathrm{AA}$ amyloidosis, $\mathrm{AA}=$ arthritis with $\mathrm{AA}$ amyloidosis, AL/ATTR $=\mathrm{AL}$ amyloidosis and ATTR amyloidosis. $\mathrm{CRP}=\mathrm{C}$ reactive protein, $\mathrm{SAA}=$ serum amyloid $\mathrm{A}$ protein. NA denotes not applicable. ${ }^{\star} \mathrm{p}<0.05, \dagger \mathrm{p}<0.01$, and $\neq \mathrm{p}<0.001$ versus the AA group.

group). The causes of the arthritis were rheumatoid arthritis in 17 patients, ankylosing spondylitis in three patients, juvenile chronic polyarthritis in two patients, psoriatic arthritis in one patient, and SAPHO (an acronym derived from synovitis, acne, pustulosis, hyperostosis, and osteitis) in another patient. Three groups served as controls: 22 members of the hospital staff and patients without arthritis (Control group), 25 patients with active rheumatoid arthritis for many years without clinical signs of amyloidosis (RA group), and 25 patients with other types of systemic amyloidosis (19 with the AL type and six with familial amyloidosis of the ATTR type) and a positive Congo red stain of the fat tissue (AL/ATTR group). Rheumatoid arthritis was defined by the ARA revised criteria. ${ }^{12}$ The systemic nature of the amyloidosis was assessed by the detection of amyloid in biopsy specimens from at least two different tissues or organs. Amyloid of the AA type was demonstrated by reactivity with anti-AA antibodies in immunohistology. Amyloid of the ATTR type was demonstrated by a family history of amyloidosis, the presence of a variant transthyretin by DNA analysis, and reactivity with anti-TTR antibodies in immunohistology. Amyloid of the AL type was demonstrated by signs of a clonal plasma cell dyscrasia, such as the presence of a light chain in serum or urine detected by immunofixation electrophoresis or the presence in the bone marrow of a relative excess of cells producing one of the light chains, and the lack of reactivity with anti-AA and anti-ATTR antibodies in immunohistology. The study was approved by the local ethical committee. All patients and controls gave their informed consent. Table 1 shows the characteristics of the patients and the controls.

FAT ASPIRATION

Skin and subcutaneous tissue on both sides of the umbilicus of the patients and controls were anaesthetised with lidocaine. The aim was to aspirate at least $30 \mathrm{mg}$ of fat tissue to enable the quantification of amyloid A protein, and adequate material to enable microscopy with Congo red staining. The fat tissue was aspirated with a needle of 16 gauge connected to a syringe of $10 \mathrm{ml} .^{13} \mathrm{~A}$ small quantity (0.4 $\mathrm{ml}$ ) of sodium citrate $(0.109 \mathrm{M})$ was present in the syringe to prevent clotting of accidentally obtained blood. The procedure was performed on both sides of the umbilicus to obtain two different samples that were used to calculate the within subjects coefficient of variation of the new method. However, if the fat tissue in one of the samples weighed less than $30 \mathrm{mg}$, the two samples were combined.

\section{MICROSCOPY}

At least four visible fragments of fat tissue were put on each of three glass slides and crushed into a single cell layer by pressing a second slide perpendicularly to the first. The three smears were dried in the air at room temperature, fixed with acetone, and stained with alkaline Congo red dye according to Puchtler. ${ }^{14}$ The affinity of tissue for Congo red was analysed by the apple-green birefringence in polarised light using the Olympus BX 50 microscope, 100 Watt. Two independent and blinded investigators (JB and $\mathrm{BPCH}$ ) scored all slides in a random order and semi-quantitatively: (0), no apple-green birefringence detectable; $(1+)$, minute deposits; (2+), moderate deposits; (3+) extensive deposits. Subsequently, the three slides of each individual patient were scored simultaneously to obtain one final score for the individual patient. When the two blinded investigators scored a patient differently, the three slides were discussed to obtain a final score for the patient.

\section{PREPARATION AND EXTRACTION OF THE FAT} TISSUE ASPIRATES

The fat tissue was collected from the syringe and separated from the sodium citrate fluid, weighed (wet weight), and washed three times for 10 minutes with $1 \mathrm{ml}$ of phosphate buffered saline (PBS) to remove possible remnants of blood. The washed fat tissue was extracted in 1 $\mathrm{ml}$ of a solution of $0.1 \mathrm{M}$ TRIS $\mathrm{HCl}, \mathrm{pH} 8.0$, and $6 \mathrm{M}$ guanidine hydrochloride and this suspension was shaken continuously at room temperature overnight. The suspension was centrifuged at $10000 \times \mathrm{g}$ for 10 minutes and the supernatant fat tissue extract was collected. The total protein concentrations in the fat tissue extracts were measured with the Pyrogallol red method (Instruchemie, Hilversum, the Netherlands) and expressed in albumin equivalents. ${ }^{15}$ The pellets were stained with 
Congo red and extracted again to assess the efficiency of the extraction procedure.

QUANTIFICATION OF THE AMYLOID A

CONCENTRATION OF FAT TISSUE EXTRACTS

The concentration of amyloid A protein was measured in the fat tissue extracts by a monoclonal antibody-based sandwich ELISA as described previously for serum samples. ${ }^{16}$ Human SAA was purified from the HDL3 fraction of acute phase serum. The purified apo-SAA was linked to helix pomatia haemocyanin and injected into Balb/c mice to produce monoclonal antihuman-SAA antibodies. One monoclonal antibody Reu.86.2 (ICN Biomedicals, Zoetermeer, the Netherlands) displays a high affinity for tissue deposits of amyloid A protein in immunohistochemistry. ${ }^{17}$ Two other monoclonal antibodies Reu.86.5 and Reu.86.1 demonstrate high affinity for purified SAA and for purified amyloid A protein both in ELISA and in immunoblotting techniques. Monoclonal antibody Reu.86.5 reacts with all acute phase subtypes of SAA, whereas Reu.86.1 reacts only with SAA1, the major SAA subtype. Reu.86.5 and Reu.86.1 were used in the sandwich ELISA.

Microtitre plates ( $\mathrm{HB}, \mathrm{FB}$, Corning Costar, Badhoevedorp, the Netherlands) were coated at room temperature on an EASIA shaker (500 $\mathrm{rpm}$ ) with the IgG fraction of the pan-reactive capture antibody Reu.86.5 (diluted to 0.5 $\mu \mathrm{g} /$ well in $0.01 \mathrm{M}$ PBS, $\mathrm{pH} 7.4$ ) during one hour. Then the plates were washed with the washing solution of $0.025 \mathrm{M}$ TRIS- $\mathrm{HCl}, \mathrm{pH}$ 8.0, 0.15 M NaCl, and 0.05\% Tween-20. This was followed by incubation of the samples in serial dilutions, starting with 1:20. Incubations were done in duplicate at room temperature on the EASIA shaker in 0.01 M PBS, pH 7.4, $1 \%$ BSA, and $0.05 \%$ Tween- 20 in a final volume of $0.1 \mathrm{ml} /$ well during one hour. The plates were washed, followed by incubation with the $\mathrm{IgG}$ fraction of the SAA1 reactive detection antibody Reu.86.1 coupled to horseradish peroxidase (diluted to $0.2 \mu \mathrm{g} /$ well in $0.01 \mathrm{M} \mathrm{PBS}$, $\mathrm{pH}$ 7.4). One $\mathrm{mg}$ of the chromogen 3'3'5'5'tetramethylbenzidin (TMB, Carl Roth, Karlsruhe, Germany) was dissolved in $11 \mathrm{ml}$ $0.1 \mathrm{M}$ acetate buffer, $\mathrm{pH} \quad 6.0$, and $0.004 \%$ $\mathrm{H}_{2} \mathrm{O}_{2}$. After washing, the plates were incubated with the chromogen solution at room temperature until the reaction was stopped after 20 minutes by the addition of $1 \mathrm{M} \mathrm{H}_{2} \mathrm{SO}_{4}$. The absorption at $450-575 \mathrm{~nm}$ was read in an Emax microplate reader and the concentrations were calculated by SOFTmax PRO software (Molecular Devices, Sunnyvale, USA). Reconstitution of an exact quantity of purified apo-SAA into normal plasma provided the ultimate standard of the assay. Recently the international standard for SAA protein $(0.15$ IU per ampoule, WHO code 92/680) has been published, ${ }^{18}$ and we recalculated the standard of our assay according to this WHO standard. No effects were seen of sample storage, repeatedly freezing and thawing, or the addition of increasing concentrations of guanidine hydrochloride in the assay (up to $0.75 \mathrm{M}$ ). The intra-assay and interassay coefficients of varia- tion were both less than $10 \%$; the lower limit of detection of the amyloid A protein was 1.6 $\mathrm{ng} / \mathrm{ml}$ (or $1.6 \mu \mathrm{IU} / \mathrm{ml}$ ).

SERUM ACUTE PHASE PROTEINS

Blood concentrations of SAA were measured by ELISA as described above. Basal control values of healthy controls are below $4.2 \mathrm{mg} / \mathrm{l}^{16}$ Blood concentrations of $\mathrm{C}$ reactive protein (CRP) were measured by ELISA. No effects were seen of sample storage or the addition of increasing concentrations of guanidine hydrochloride in the assay (up to $0.75 \mathrm{M}$ ). Basal control values of healthy controls are below 2.1 $\mathrm{mg} / \mathrm{l}^{19}$

IMMUNOBLOTTING OF FAT TISSUE EXTRACTS

Fat tissue extracts of the patients and controls were applied to a mini-gel format (MiniProtean II, Biorad, Veenendaal, the Netherlands) of a $15 \%$ sodium dodecyl sulphate poly acrylamide gel (SDS-PAGE), according to the method of Laemmli. ${ }^{20}$ The proteins were separated by this SDS-PAGE technique and electroblotted onto a nitro-cellulose sheet. Remaining binding sites were blocked with $4 \%$ milk powder dissolved in 0.01 M PBS, then incubated with the pan-reactive antibody Reu.86.5, followed by incubation with rabbit antimouse immunoglobulin coupled to horseradish peroxidase (Dakopatts, Copenhagen, Denmark), and finally visualised with the chemiluminescence technique (SuperSignal Substrate, Pierce, Rockford, IL, USA). Rainbow molecular weight markers were used in the range from 2.35 to $46 \mathrm{kDa}$ (Amersham, Buckinghamshire, UK).

\section{STATISTICAL METHODS}

The $\kappa$ statistic was used to measure the interobserver agreement of the two blinded investigators who scored the Congo red stained slides. ${ }^{21}$ Statistical analysis was performed by using the statistical package GraphPad Prism, version 2.01 (GraphPad Software Inc, San Diego, CA, USA). Non-parametric tests were used all the time. The Mann-Whitney test was used for differences between two unpaired groups. The Kruskal-Wallis test was used in combination with Dunn's multiple comparison test to detect differences of the patients' characteristics, serum acute phase proteins, and fat tissue measurements between the patients with AA amyloidosis and the other three groups. These tests were also used for differences of concentrations of amyloid A protein in fat tissue between patients with AA amyloidosis having more or less amyloid in the fat smears stained with Congo red. The Spearman test for correlation was used in patients with AA amyloidosis to detect correlations between the amyloid A protein concentration and variables such as age, disease duration, and acute phase proteins. In all tests two tailed $\mathrm{p}$ values $<0.05$ were considered significant.

\section{Results}

The aspiration of fat was a gentle and almost painless procedure, without any adverse effects 


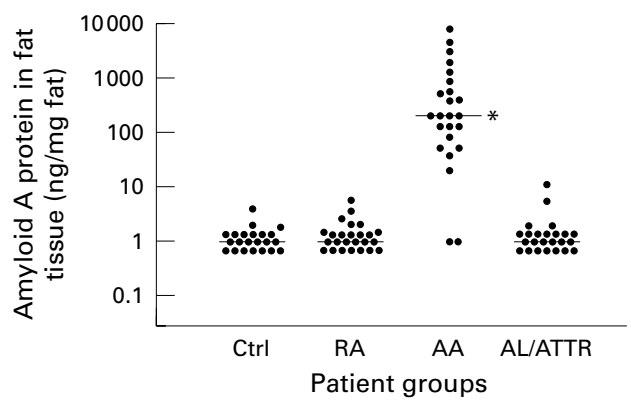

Figure 1 The amyloid $A$ protein concentration $(\mathrm{ng} / \mathrm{mg}$ tissue) of aspirated fat tissue of 22 controls, 25 patients with rheumatoid arthritis without $A A$ amyloidosis $(R A), 24$ patients with arthritis and $A A$ amyloidosis $(A A)$, and 25 patients with AL or ATTR amyloidosis (AL/ATTR). Horizontal lines indicate median values. The limit of detection is $1.1 \mathrm{ng} / \mathrm{mg}$ fat tissue. The asterisk ( $\left.{ }^{\star}\right)$ indicates the difference $(p<0.001)$ between the patients with arthritis and $A A$ amyloidosis and each of the three other groups.

except for bruising in some patients and controls. In all cases bruising was minor and self limiting.

The lower detection limit for measuring amyloid A protein in fat extracts (diluted 1:20) was $32 \mathrm{ng} / \mathrm{ml}$. The volume of the suspension in which at least $30 \mathrm{mg}$ of fat tissue was extracted was $1 \mathrm{ml}$ and the lowest concentration of protein found in this volume was $0.27 \mathrm{mg} / \mathrm{ml}$. Therefore the lower detection limits for measuring amyloid A protein in fat extracts were 1.1 $\mathrm{ng} / \mathrm{mg}$ fat tissue and $0.11 \mu \mathrm{g} / \mathrm{mg}$ protein. The within subjects coefficient of variation $(\mathrm{CV})$ was $22 \%$. To calculate this $\mathrm{CV}$, ample fat tissue (wet weight more than $30 \mathrm{mg}$ ) was obtained from each side of the umbilicus in 18 of the 24 patients with AA amyloidosis.

The amyloid A protein concentration of fat tissue was higher $(p<0.001)$ in the group of patients with AA amyloidosis (median 236 $\mathrm{ng} / \mathrm{mg}$ tissue) than in each of the three control groups (median values of all three groups 1.1 $\mathrm{ng} / \mathrm{mg}$ tissue), as shown in figure 1 . The results were comparable whether the concentration of amyloid A protein was expressed in $\mu \mathrm{g} / \mathrm{mg}$ protein or in $\mathrm{ng} / \mathrm{mg}$ tissue (see table 1 ). In the two patients with AA amyloidosis and amyloid A protein values below $11.6 \mathrm{ng} / \mathrm{mg}$ tissue (the upper limit of the controls), amyloid could neither be detected in the fat smears stained with Congo red (see below). When the upper limit of controls (11.6 ng/mg tissue) was chosen as the cut off level, the specificity of the new method to detect AA amyloidosis was 72 of 72 $(100 \%)$ and the sensitivity was 22 of $24(92 \%)$. In only $13(18 \%)$ of the 72 subjects of the three control groups the amyloid A protein concentration was above the detection limit of 1.1 $\mathrm{ng} / \mathrm{mg}$ tissue.

The two investigators did not detect any amyloid in the Congo red stained fat smears of any of the 22 healthy controls nor in any of the 25 patients with rheumatoid arthritis. Amyloid was detected in the fat smears of 22 of the 24 patients with AA amyloidosis. The interobserver $\kappa$ of the slide scores of these patients with AA amyloidosis was 0.61 and the $\kappa$ of the final patient scores was 0.88 . When the patients with AA amyloidosis were arranged in order of

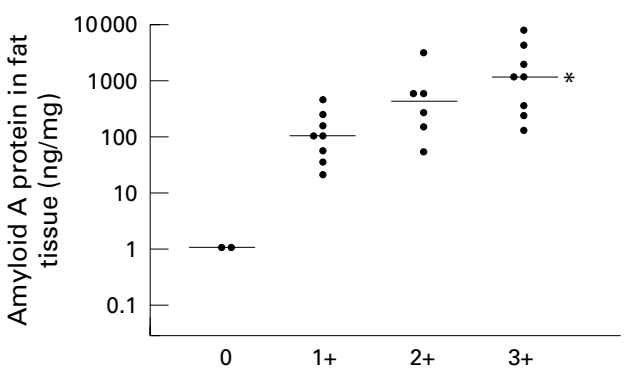

Score of amyloid deposition (Congo red)

Figure 2 The amyloid $A$ protein concentration of aspirated fat tissue (ng/mg tissue) of 24 patients with $A A$ amyloidosis divided into four groups with increasing deposition of amyloid in fat smears. The deposition of amyloid was scored by staining the smears with Congo red. Horizontal lines indicate median values. The asterisk ( $\left.{ }^{\star}\right)$ indicates the difference $(p<0.05)$ between the eight patients with extensive deposits $(3+)$ and the eight patients with minute deposits $(1+)$. No difference was found between the six patients with moderate deposits $(2+)$ and the other groups.

the final score of amyloid deposition in the Congo red stained smears, the median amyloid A protein concentration increased parallel to this score, as shown in figure 2. Deposition of amyloid was absent $(0)$ in two, minute $(1+)$ in eight, moderate $(2+)$ in six, and extensive $(3+)$ in eight patients. The concentration of amyloid A protein was higher $(\mathrm{p}<0.05)$ in the patients with extensive (3+) deposits than in the patients with minute $(1+)$ deposits (median $1240 v 110 \mathrm{ng} / \mathrm{mg}$ ). When amyloid was present, its presence was not always detected in all three glass slides of a patient. Amyloid was overlooked four times in one of the three glass slides, twice by each observer, namely in three patients with minute $(1+)$ deposition and in one patient with moderate $(2+)$ deposition.

The amyloid A protein concentration of fat tissue of the 17 patients with AA amyloidosis and rheumatoid arthritis (median $358 \mathrm{ng} / \mathrm{mg}$ ) did not differ significantly from the seven patients with other types of arthritis (median $144 \mathrm{ng} / \mathrm{mg}$ ). In none of the 24 patients with AA amyloidosis a correlation was found between the amyloid A protein concentration of fat tissue and the age of the patients, the duration of the AA amyloidosis and the arthritis, and the blood concentrations of SAA and CRP. Table 1 shows the blood concentrations of CRP and

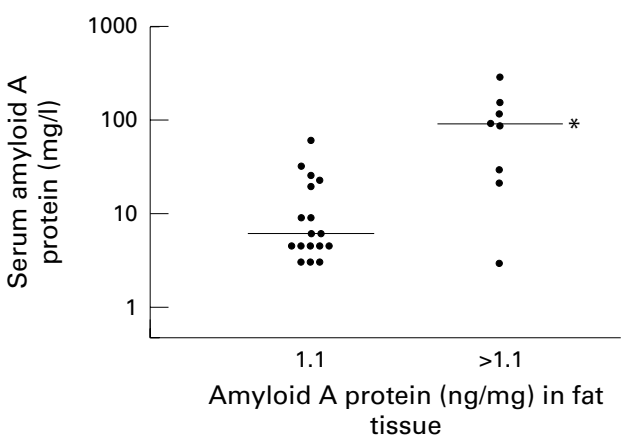

Figure 3 The serum amyloid A protein (SAA) levels (mgll) of the 25 patients with rheumatoid arthritis without AA amyloidosis. Horizontal lines indicate median values. The asterisk $(*)$ indicates the difference $(p<0.01)$ between the eight patients with a measurable amyloid $A$ protein concentration of fat tissue $(>1.1 \mathrm{ng} / \mathrm{mg})$ and the 17 patients without a measurable concentration $(1.1 \mathrm{ng} / \mathrm{mg})$. 


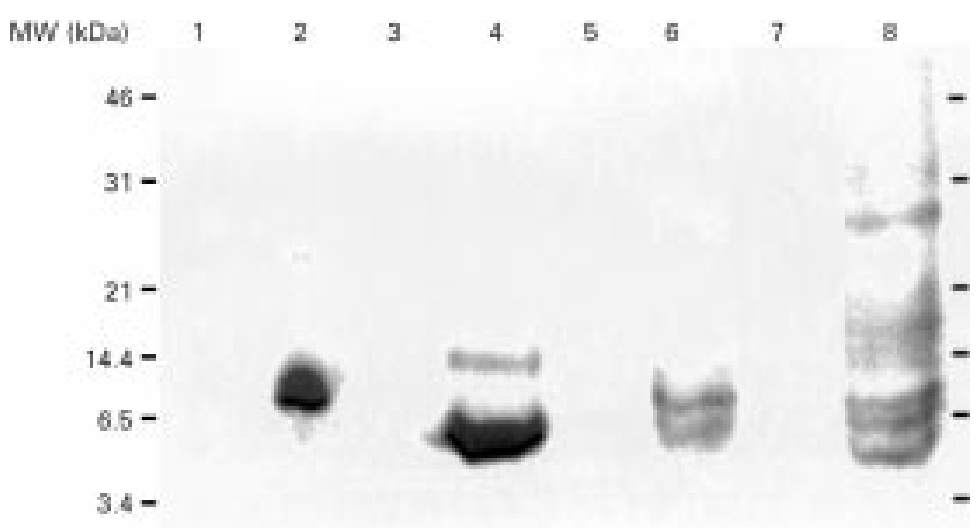

Figure 4 SDS-PAGE of non-acute phase serum (lane 1), acute phase serum (lane 2), fat extracts (lane 3-8) of a healthy control (lane 3), of patients with arthritis and AA amyloidosis (lane 4, 6, and 8), of a patient with rheumatoid arthritis without AA amyloidosis (lane 5), and of a patient with AL amyloidosis (lane 7) run on $15 \%$ polyacrylamide gel, immunoblotted, detected with the monoclonal antibody Reu. 86.5 raised against serum amyloid $A$, followed by a chemiluminescence technique. Rainbow molecular weight markers were chosen from 2.35 to $46 \mathrm{kDa}$ (Amersham, Buckinghamshire, UK).

SAA of the four groups. No difference was found between the SAA concentrations of the arthritic patients with AA amyloidosis and the patients with uncomplicated rheumatoid arthritis. The SAA concentrations of the eight patients with uncomplicated rheumatoid arthritis and measurable amyloid A protein concentrations of fat tissue - that is, above $1.1 \mathrm{ng} / \mathrm{mg}$, were higher (median $93 \mathrm{mg} / \mathrm{l} v 6.2 \mathrm{mg} / \mathrm{l}, \mathrm{p}<$ 0.01 ) than the SAA concentrations of the 17 patients without measurable concentrationsthat is, $1.1 \mathrm{ng} / \mathrm{mg}$ (fig 3).

Immunoblotting of fat tissue extracts with anti-AA antibodies showed coexistence of relatively large serum amyloid A-like protein bands (about $12-14 \mathrm{kDa}$ ) as well as smaller amyloid A-like protein bands (ranging in size from 10 to $4 \mathrm{kDa}$ ) in some patients with AA amyloidosis (fig 4). The same bands were observed with the SAA1 reactive antibody Reu.86.1 (although the intensity was somewhat weaker) and with a polyclonal rabbit anti-amyloid A protein antibody RA-29 (data not shown). After extraction of the fat tissue with guanidine, the remaining pellets were stained with Congo red. No amyloid was observed in the Congo red stained pellets of patients with extensive deposition of amyloid in the fat smears. The amyloid A protein concentrations in the re-extracts of these pellets were lower than $4.2 \mathrm{ng} / \mathrm{mg}$ of the original fat tissue (and less than $2 \%$ of the value of the first extracts).

\section{Discussion}

We have described a new, quantitative, and reproducible method for detecting deposits of amyloid A protein in aspirated fat tissue of patients with arthritis. A concentration of amyloid A protein higher than $11.6 \mathrm{ng} / \mathrm{mg}$ tissue appears to be diagnostic for AA amyloidosis. Very promising is the finding in this study that all 22 Congo red positive biopsy specimens were identified with this method (concentration of amyloid A protein ranging from 21.9 to $8530 \mathrm{ng} / \mathrm{mg}$ tissue). The higher concentration of amyloid A protein in fat extracts from AA patients with more extensive deposition of amyloid in the Congo red stained smears sug- gests that this quantitative measurement may represent an estimation of the amount of amyloid present in fat tissue. The highest value of amyloid A protein was $515 \mu \mathrm{g} / \mathrm{mg}$ protein (see table 1), which would mean that amyloid A protein can constitute up to $51 \%$ of all protein in fat tissue.

Both sensitivity and specificity of the method for detecting AA amyloidosis seem to be appropriate, although this should be confirmed in a larger group of patients with AA amyloidosis of variable duration and severity, as well as in larger control groups. If the prevalence of AA amyloidosis is $5 \%$ in patients with rheumatoid arthritis, the figures found for sensitivity, 92\% (95\% confidence intervals $73 \%$, 99\%), and for specificity, $100 \%$ (97.5\% confidence intervals $95 \%, 100 \%$ ), will yield a positive predictive value of $100 \%$ and a negative predictive value of $99 \%$. The coefficient of variation between the amyloid A protein concentration on either side of the umbilicus (within the patient) was $22 \%$. This within subjects coefficient of variation shows the good reproducibility of the method. The interobserver agreement of the standard Congo red method was good $(\kappa$ of the slide scores was 0.61 ) to very good ( $\kappa$ of the final scores was 0.88 ). However, it appeared to be useful to score three glass slides of an individual patient because in some patients (especially those with minute deposits of amyloid) amyloid was overlooked in one of the three glass slides by one of the two observers.

The new method is not the first published assay for the quantification of amyloid A protein in tissue. Amyloid A protein has already been quantified by inhibition ELISA in small samples (10-60 mg) of mouse and human necropsy tissues of the spleen. ${ }^{10}$ However, our new sandwich ELISA offers at least three important advantages. The first advantage is that the extracted material can be used directly in the assay instead of first being lyophilised. The second advantage is the general availability and constant quality of the assay by using monoclonal instead of polyclonal antibodies. The third advantage is its applicability to aspirated fat tissue of live patients instead of necropsy tissues. However, a possible disadvantage of the assay may be the lack of reactivity of the SAA1 reactive monoclonal antibody Reu.86.1 with SAA2. Although other techniques can detect amyloid A deposition in fat tissue of live patients, such as immunodiffusion, ${ }^{22}$ immunoblotting, ${ }^{23}$ and immunofluorescence microscopy, ${ }^{24}$ these techniques provide qualitative instead of quantitative results. Having quantitative instead of qualitative information concerning amyloid A protein may be important for monitoring disease progression or the results of treatment. This will be studied in the near future.

The immunoblotting technique of this study also provided qualitative results that confirm the presence of amyloid A protein-like material in the fat extracts (see fig 4). Amyloid A protein has a molecular weight of about $8 \mathrm{kDa}$, whereas its serum precursor SAA has a molecular weight of about $12 \mathrm{kDa}$. Immunoblotting with polyclonal and monoclonal anti-SAA antibodies showed several bands with molecular 
weights ranging between 10 and $4 \mathrm{kDa}$, indicating the presence of amyloid A protein and some of its degradation products. Although monoclonal antibody Reu.86.1 does not recognise SAA2 and its fragments, it recognised the same bands as the pan-reactive monoclonal antibody Reu.86.5 and the polyclonal antibody RA-29. It remains speculative whether the $12-14 \mathrm{kDa}$ band (see lane 4 of fig 4) represents "fresh" or "ongoing" deposition of SAA into amyloid, dimers of smaller amyloid A fragments, or pollution with SAA from accidentally obtained peripheral blood. The absence of this band in controls with raised serum SAA concentrations make the latter explanation less likely.

Concentrations of amyloid A protein in fat tissue above the detection limit were found in $18 \%$ of the 72 controls (see fig 1). In RA patients without AA amyloidosis, the SAA blood concentrations were higher in patients with measurable amyloid A protein levels in fat tissue than in those without. Although the tissue was washed vigorously, pollution with SAA from accidentally obtained peripheral blood (with concentrations about 100 times higher than those of the fat tissue) will be the most likely explanation. Theoretically, however, some amyloid A protein has to be present in fat tissue as a substrate for the generation of amyloid A fibrils. In this respect, the presence of measurable amyloid A protein in fat tissue in patients with high serum SAA concentrations might be related to a normal role in fat tissue of SAA as an HDL3-associated apolipoprotein. If this is the case, the pathophysiological phenomenon of amyloid A deposition in fat tissue might be linked to a derangement of the normal function of SAA.

Amyloid deposition is a dynamic process that can progress, stabilise, and regress. The dynamics of this process has been documented by clinical examination, organ function assessment, echography, and serum amyloid P component (SAP) turnover studies. ${ }^{25}{ }^{26}$ We hypothesise that quantification of the amyloid $\mathrm{A}$ protein concentration of tissue on regular occasions will similarly reflect the accumulation, stabilisation or even regression of the amyloid deposited. Abdominal subcutaneous fat tissue seems to be very suitable for this purpose, because it is easy to obtain by aspiration and it can be obtained repeatedly. The combination of the Congo red stain with the quantitative measurement of amyloid $\mathrm{A}$ in fat tissue may thus become the microscopic counterpart of SAP scintigraphy, the best currently available tool to monitor ongoing deposition, stabilisation or regression of amyloid in the whole body. ${ }^{25}{ }^{26}$ It could be used to monitor the effect of treatment. If a partial response or even complete remission of AA amyloidosis is achievable, we will need some well defined tools to measure it.

In conclusion, this study shows that quantification of the amyloid A protein concentration of abdominal subcutaneous fat aspirates in patients with arthritis is a new, gentle, and reproducible procedure that discriminates between patients with and without AA amyloido- sis. An advantage of the new method is that minute deposits of amyloid can be detected more easily than with the standard Congo red method. Whether this method will detect amyloid earlier than the Congo red method has to be studied in a prospective way. It is also an excellent method for discriminating between AA amyloidosis and other types of systemic amyloidosis. Patients with extensive amyloid A deposits in the fat smear have higher concentrations of amyloid A protein than those with minute deposits. Therefore this new method may have the potential for monitoring actual deposition of amyloid A protein in tissue of patients with AA amyloidosis.

Financial support for this study was provided by the "The Dutch League against Rheumatism". We would like to thank Mrs. M. Zeiger, MA, and the Groningen Unit for Amyloidosis Research and Development (GUARD) for critical discussions and technical support.

1 Husby G. Amyloidosis and rheumatoid arthritis. Clin Exp Rheumatol 1985;3:173-80.

2 Kobayashi H, Tada S, Fuchigami T, Okuda Y, Takasugi K, Matsumoto T, et al. Secondary amyloidosis in patients with heumatoid arthritis: diagnostic and prognostic value of gastroduodenal biopsy. Br J Rheumatol 1996;35:44-9.

3 Janssen S, van Rijswijk MH, Meijer S, Ruinen L, van der Hem GK. Systemic amyloidosis: a clinical survey of 144 cases. Neth J Med 1986;29:376-85.

4 Gertz MA, Kyle RA. Secondary systemic amyloidosis: response and survival in 64 patients. Medicine (Baltimore) 1991;70:246-56.

5 Ahlmen M, Ahlmen J, Svalander C, Bucht H. Cytotoxic drug treatment of reactive amyloidosis in rheumatoid drug treatment of reactive amyloidosis in rheumatoid arthritis with special refere

6 David J, Vouyiouka O, Ansell BM, Hall A, Woo P. Amyloidosis in juvenile chronic arthritis: a morbidity and mortality study. Clin Exp Rheumatol 1993;11:85-90.

7 Berglund K, Thysell H, Keller C. Results, principles and pitfalls in the management of renal AA-amyloidosis; a 10-21 year followup of 16 patients with rheumatic disease treated with alkylating cytostatics. J Rheumatol 1993;20: 2051-7.

8 Janssen S, Elema JD, van Rijswijk MH, Limburg PC, Meijer S, Mandema E. Classification of amyloidosis: immunohistochemistry versus the potassium permanganate method in differentiating AA from AL amyloidosis. Appl Pathol 1985; $3: 29-38$.

9 Linke RP, Gartner HV, Michels H. High-sensitivity diagnosis of AA amyloidosis using Congo red and immunohistochemistry detects missed amyloid deposits. J Histochem Cytochem 1995;43:863-9.

10 Yakar S, Kaplan B, German G, Livneh A, Miura K, Shtrasburg S, et al. Quantification of tissue amyloid content in AA amyloidosis by inhibition ELISA. Amyloid: Int J Exp Clin Invest 1995;2:167-72.

11 Westermark P. Diagnosing amyloidosis. [Editorial]. Scand J Rheumatol 1995;24:327-9

12 Arnett FC, Edworthy SM, Bloch DA, McShane DJ, Fries $\mathrm{JF}$, Cooper NS, et al. The American Rheumatism Association 1987 revised criteria for the classification of rheumatoid arthritis. Arthritis Rheum 1988;31:315-24.

13 Westermark P. Diagnosis and characterization of systemic amyloidosis by biopsy of subcutaneous abdominal fat tissue. Internal Medicine Specialist 1984;5:154-60.

14 Puchtler H, Sweat F, Levine M. On the binding of Congo red by amyloid. J Histochem Cytochem 1962;10:355-63.

15 Watanabe N, Kamei S, Ohkubo A, Yamanaka M, Ohsawa S, Makino K, et al. Urinary protein as measured with a pyrogallol red-molybdate complex, manually and in a Hitachi 726 automated analyzer. Clin Chem 1986;32:1551-4.

16 Hazenberg BPC, Limburg PC, Bijzet J, van Rijswijk MH. Monoclonal antibody based ELISA for human SAA. In: Natvig JB, Førre Ø, Husby G, Husebekk A, Skogen B, Nletten K, et al, eds. Amyloid and amyloidosis 1990. Sletten K, et al, eds. Amyloid and amyloidosis 1990. Dordrecht: Kluwer Academic Publishers, 1981:898-901.
Hazenberg BPC, Grond J, van den Top D, Bijzet J, Limburg Hazenberg BPC, Grond J, van den Top D, Bijzet J, Limburg
PC, van Rijswijk MH. Detection of amyloid AA in rectal biopsies with a new monoclonal anti-human SAA antibody (Reu.86.2). [Abstract]. Kidney Int 1991;40:976-7.

18 Poole S, Walker D, Gaines Das RE, Gallimore JR, Pepys MB. The first international standard for serum amyloid A protein (SAA). Evaluation in an international collaborative study. J Immunol Methods 1998; 214:1-10.

19 Hazenberg BPC, Limburg PC, Bijzet J, van Rijswijk MH. SAA versus CRP serum levels in different inflammatory conditions, studied by ELISA using polyclonal anti-AA and monoclonal anti-SAA antibodies. In: Isobe T, Araki S, Uchino F, Kito S, Tsubura E, eds. Amyloid and amyloidosis. New York: Plenum Press, 1988:229-33.

20 Laemmli UK, Favre M. Maturation of the head of bacteriophage T4. I. DNA packaging events. J Mol Biol 1973;80:575-99. 
21 Altman DG. Practical statistics for medical research. London: Chapman and Hall, 1991.

22 Westermark P, Stenkvist B, Natvig JB, Olding Stenkvist E. Demonstration of protein AA in subcutaneous fat tissue obtained by fine needle biopsy. Ann Rheum Dis 1979;38: 68-71.

23 Kaplan B, German G, Pras M. Isolation and characterization of amyloid proteins using milligram amounts of amyloidcontaining tissue. J Liquid Chrom 1993;16:2249-68.

24 Orfila C, Giraud P, Modesto A, Suc JM. Abdominal fat tissue aspirate in human amyloidosis: light, electron, and immunofluorescence microscopic studies. Hum Pathol 1986;17:366-9.

25 Hawkins PN, Richardson S, Vigushin DM, David J, Kelsey CR, Gray RE, et al. Serum amyloid P component scintigraphy and turnover studies for diagnosis and quantitative monitoring of AA amyloidosis in juvenile rheumatoid arthritis. Arthritis Rheum 1993;36: $842-51$

26 Hawkins PN. Studies with radiolabelled serum amyloid P component provide evidence for turnover and regression of amyloid deposits in vivo. Clin Sci 1994;87:289-95.

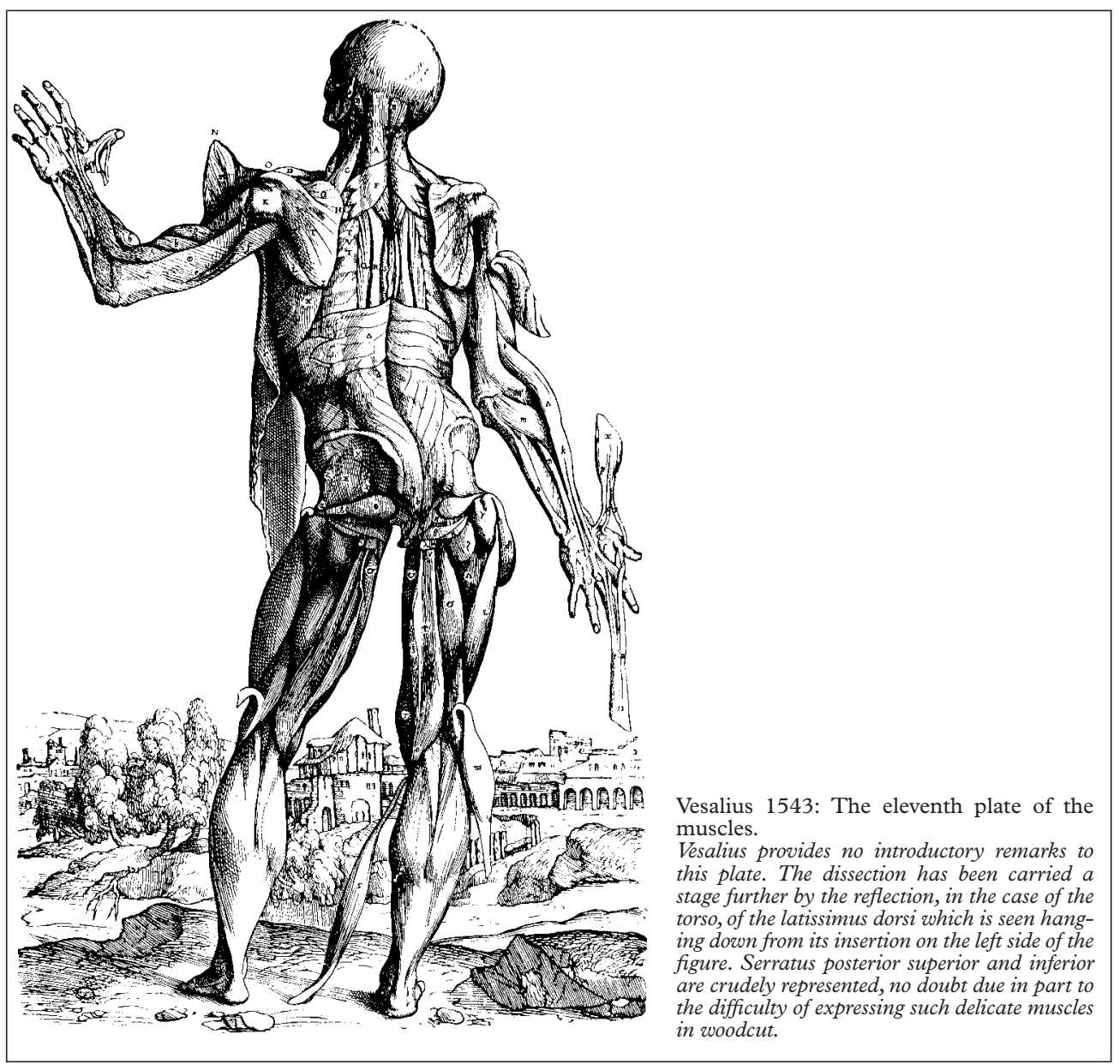

